\title{
A digital health intervention for adolescent mothers in the Dominican Republic
}

\begin{tabular}{|c|c|c|}
\hline $\begin{array}{l}\text { Adolescent mothers and their } \\
\text { babies are vulnerable to poor } \\
\text { health outcomes. For this } \\
\text { reason, it is vital to provide } \\
\text { them adequate support } \\
\text { and information to ensure } \\
\text { optimal health. Dr Samantha } \\
\text { Stonbraker and her research } \\
\text { team undertook a study to } \\
\text { identify the health information } \\
\text { needs of young mothers living } \\
\text { in the Dominican Republic and } \\
\text { design a digital intervention } \\
\text { using WhatsApp Messenger to } \\
\text { meet those needs. They then } \\
\text { tested the effectiveness of the } \\
\text { intervention. The results show } \\
\text { promise for the use of mobile } \\
\text { health technologies to support } \\
\text { adolescent mothers in this and } \\
\text { other similar settings which can } \\
\text { lead to better health outcomes. }\end{array}$ & $\begin{array}{l}\text { mproving maternal health has been } \\
\text { identified as a key goal in both the } \\
\text { UN's Millennium Development Goals } \\
\text { and Sustainable Development Goals. To } \\
\text { achieve these goals, health care providers } \\
\text { and organisations must be able to } \\
\text { support mothers and their babies who are } \\
\text { vulnerable to poor health outcomes. } \\
\text { Adolescent mothers and their babies are } \\
\text { known to be at high risk of sub-optimal } \\
\text { health outcomes such as preterm } \\
\text { delivery, anaeemia, and postpartum } \\
\text { haemorrhage for mothers and low } \\
\text { birth weight for babies. Additionally, } \\
\text { childbirth in adolescence can have } \\
\text { profound lifetime effects on the mother } \\
\text { and baby, as it can interrupt the mother's } \\
\text { education and ultimately, lifetime } \\
\text { earnings which can in turn impact the } \\
\text { development of her child as well as } \\
\text { wider society. Notably, the postpartum } \\
\text { period (the six weeks after a mother } \\
\text { gives birth) is particularly challenging } \\
\text { for new mothers as they adapt to } \\
\text { taking care of both their baby and } \\
\text { themselves. Therefore, young mothers } \\
\text { have specific and highly important } \\
\text { health information needs that must } \\
\text { be met during this period. Consistent } \\
\text { informational and social support } \\
\text { during this adaptation to motherhood } \\
\text { can reduce the risk of postpartum } \\
\text { depression for young mothers, and } \\
\text { improve other health outcomes. } \\
\text { To reach adolescent mothers living in } \\
\text { and around La Romana, Dominican } \\
\text { Republic, Dr Samantha Stonbraker and } \\
\text { her colleagues at Planned Parenthood of } \\
\text { the Great Northwest and the Hawaiian } \\
\text { Islands and Clinica de Familia La Romana } \\
\text { designed an intervention delivered } \\
\text { through a digital platform, WhatsApp } \\
\text { Messenger (WhatsAppp. This intervention } \\
\text { builds on the fact that mobile health }\end{array}$ & $\begin{array}{l}\text { technologies have developed rapidly } \\
\text { over the past decade, are available } \\
\text { worldwide, and are particularly relevant } \\
\text { for adolescents who tend to use mobile } \\
\text { phones as a key communication tool. In } \\
\text { addition, mobile technologies can be } \\
\text { widely beneficial in reaching people who } \\
\text { live in spaces with limited access to health } \\
\text { resources, such as those living in rural } \\
\text { settings or developing countries, such as } \\
\text { the Dominican Republic. } \\
\text { STRENGTHENING THE } \\
\text { SELF-DETERMINATION OF } \\
\text { ADOLESCENT MOTHERS } \\
\text { The intervention Dr Stonbraker and } \\
\text { her team designed is called FAMA } \\
\text { (Fortaleciendo la Autodeterminación } \\
\text { de Madres Adolescentes), which can } \\
\text { be translated as 'Strengthening the } \\
\text { Self-Determination of Adolescent } \\
\text { Mothers'. This project was designed as an } \\
\text { intervention study to support adolescent } \\
\text { mothers who receive senvices at Clinica } \\
\text { de Familia La Romana in the Dominican } \\
\text { Republic. The Dominican Republic has one } \\
\text { of the highest rates of teenage pregnancy } \\
\text { in the world, as } 22 \% \text { of } 15-1 \text {-year-olds } \\
\text { either are, or have been, pregnant. } \\
\text { Dr Stonbraker says there is limited } \\
\text { knowledge about the specific health } \\
\text { information needs of this group of } \\
\text { mothers. Thus, it was important to identify } \\
\text { their rspecific needs so they could design a } \\
\text { tailored intervention to meet them. }\end{array}$ \\
\hline
\end{tabular}

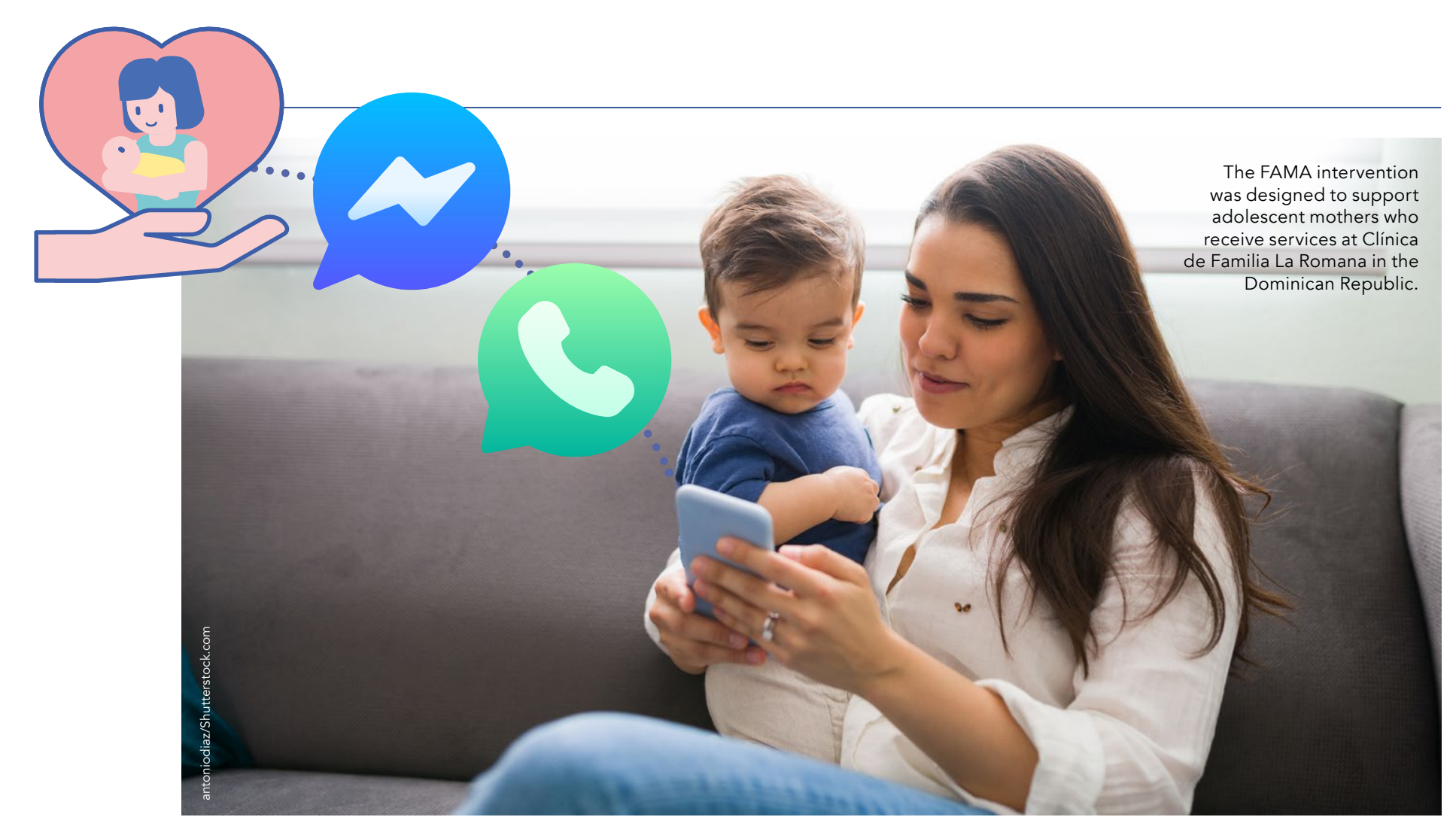

provide to their babies as well as improve postpartum period and identified their their own health outcomes. Dr Stonbraker needs for information about their baby's says that mobile health technologies, health and wellbeing, as well as for their such as WhatsApp, can be leveraged to own self-care. The participants worked deliver this information, particularly in Latin together as a group to prioritise which America and the Caribbean where more information was most important, and than $60 \%$ of people use WhatsApp for these priorities were included in a manual voice and text messaging. produced for intervention implementation.

IDENTIFYING THE INFORMATION NEEDS OF ADOLESCENT MOTHERS e information needs of adolescent mothers in this context, Dr Stonbraker and her team adopted a user-centred design a group of young a group of young
mothers volunteered to share their

experiences and identify their health information needs. At the same tim the research team asked participants questions about their current mobile phone and WhatsApp use. Dr Stonbraker explains that this inclusive approach improves the relevance, acceptability, and usefulness of the information included in health interventions and that a thorough understanding of target end users' ability to interact with technology is critical to intervention success.

To this end, design sessions were held with 24 research participants who discussed Some of the priorities identified by the group included a need for information on understanding their baby; breastfeeding; DIGITAL EDUCATIONAL SUPPORT GROUPS Once the information needs of prioritised and the corresponding manual developed, the research. team implemented a series of digital educational support groups with 58 new adolescent mothers. The average age of these mothers was 18 years old, with an age range of 15-20 years. Most of these mothers (93\%) were first

Mobile technologies can be widely beneficial in reaching people who live in spaces with limited access to health resources.

childhood illnesses; child nutrition; and available family pla

Dr Stonbraker says that an unexpected but very important finding from this phase of the study was that despite reports indicating cell phone use is ubiquitous globally, less than half (45\%) of the participants had access to a mobile phone and that none of the participants had a data plan so they relied on wi-fi or small data packages for mobile connectivity. Despite less than expected access to mobile phones experience using 7 hat of time mothers and $40 \%$ of the group was currently In total, $97 \%$ of the adolescent mothers were $79 \%$ were married or had a domestic partner. Out of those who were married or had a partner, $67 \%$ described themselves as being financially dependent on that partner.

The digital educational support groups were implemented using WhatsApp, with an intent to concurrently provide peer and preasth inal support as well as needed intertictionts. The whether in was evaluated by establishing whether intervention participation esuled in mproved healh outcomes ind health behaviours. Measures of modern contraceaption knowledge; 


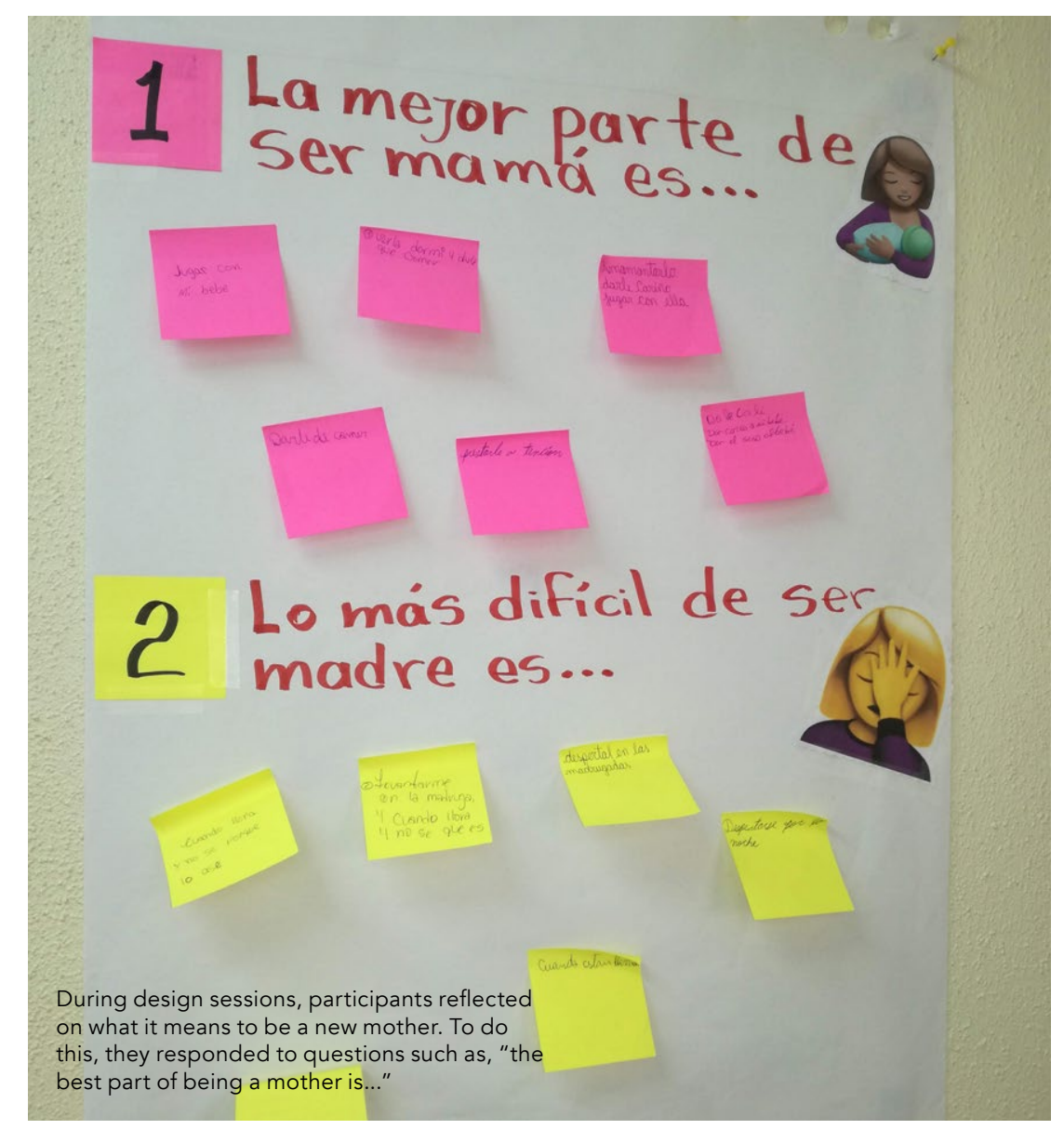

Intervention participants showed an improvement in health knowledge and were more likely to attend scheduled well-baby appointments than non-participants.

ts scheduled well-baby appointments self-reported autonomous functioning.

This mixed-method evaluation included three data collection components. The first entailed the administratio of a questionnaire to participants at baseline (before the intervention) and to follow-up (after the intervention) time points. These questionnaires included health literacy screener, questions to ascertain health-related knowledge, and assessments of autonomy and sociad support. This data was analysed using relevant statistical methods to identify followces between the baseline and follow-up assessments. Second, a so that attendance at scheduled
MPROVNG HEALTH OUTCOMES FOR ADOLESCENT MOTHERS intervention ipp support gro ap during 20,000 messages, on 10,000 enols and 1,582 pictures exchanged. This content moderated by the res. This in the Wha we exceptioly active eam, included information about healt DrStonbraker says their analysis showed statistically significant findings with important implications for improving adolescent mothers' health. This included that participants showed an improvement in their health knowledge following intervention participation, were much more likely to attend scheduled wellbaby appointments than similar mothers who did not receive the intervention, and demonstrated much higher levels of modern contraceptive use than a nationa sample of adolescents.

In addition, most of the group reported n increased sense of social connection and support, both emotionally and informationally, following intervention participation, although those results w $60 \%$ of participants expressed that they valued learning and understanding more about their baby. Many of the mothers. in the study reported that they felt more capable of autonomous functioning after intervention participation, with $78 \%$ valuing their learnings about family planning methods. The research participants also reported feeling positive about the intervention and expressed tha they had found it useful as new mothers.

The results of this study are important for numerous reasons. Dr Stonbrak highlights that the success of the intervention demonstrates it is possible to get health information to adolescent mothers through mobile technologies, What intervention also indicates that affordable and accessible health programmes can be implemented using mobil health technologies to reach people in remote locations, who may otherwise face prohibitive barriers to accessing health information. This has important implications for achieving previously established health goals, and most importantly, improving health, within rura settings and developing countries. One of the challenges highlighted in this study was that not all the adolescent mothers had access to mobile phones and the data required for consistent connectivity, and that the success of these intervention may, therefore, rely on ensuring digit

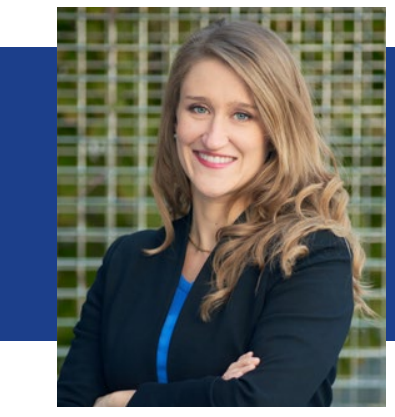

\section{Behind the Research}

Dr Samantha Stonbraker

\section{Detail}

Address

Samantha Stonbraker, 13120 E $19^{\text {th }}$ Ave

Aurora CO 80045, USA

Samantha Stonbraker PhD, MPH, RN is an Assistant Professor at the University of Colorado College of Uursing in Aurora Colorado, USA. Her work focuses on using information visualisation vunerability both nationally and internationally.

\section{Funding}

This project was supported by Grand Challenges Canada, award number ST-POC-1808-17557. Grand Challenges Canada is funded by the Government of Canada and is dedicated to supporting Bold Ideas with Big Impact ${ }^{\oplus}$.

Dr Stonbraker was funded through National Institute of Nursing Research of the National Institutes of Health under Award Numbers K99NRO17829 and ROONR017829. The content is solely the responsibility of the authors and does not necessamly represent the official views of the $\mathrm{National}$ Institutes of Heal

Collaborator

Elizabeth Haight, Alana Lopez, Linda Guijosa, Eliza Soriano, Vivian Araujo, Luz Messina and Mina Halyern.

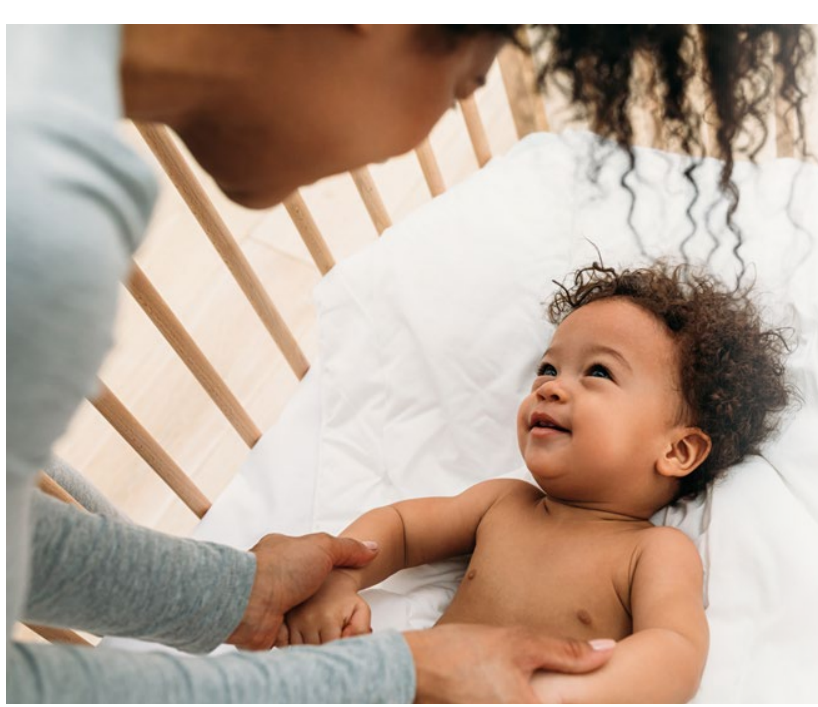

Samantha Stonbraker and her research team designed an .

\section{References}

Stonbraker, S Haight, E Soriano, L Guijosa, L Davison, E Bushley, D Messina, L \& Halpern, M (2020). Establishing adolescent mothers in the Dominican Republic: a userceleced design approach. International Journal of Adolescent Medical Health. https://doi.org/10.1515/ ijamh-2020-0054

Stonbraker, S Haight, E Lopez, A Guijosa, L Davison, E Bushley, D Peguero, K Araujo, V Messina, L \& Halpern, M (2021) Digital Educational Support Groups Administered through WhatsApp Messenger Improve Health-Related Knowledge and Health Behaviors of New Adolescent Mothers in the Dominican Republic: A Mult-Method Study. Informatics, 7(4). doi:10.3390/informatics7040051

\section{Personal Response}

What are some of the future priorities if we aim to improve health outcomes of adolescent mothers? I To improve health outcomes of young adolescent to understand the specific challenges and needs experienced by the mothers in each unique context so interventions can be tailored accordingly. Once the specific needs and challenges of young mothers in each a tremendous resource and opportuty to meet those a tremendous resource and opportunity to meet those may otherwise be difficult or prohibitive.

말 College of Nursing Und 